IKONOMIKA: Journal of Islamic Economics and Business

Volume 2, NoI (20I7)

ISSN: 2527-3434 (PRINT) - ISSN: 2527-5I43 (ONLINE)

Page : $75-84$

\title{
Perhitungan Value at Risk Pada Portfolio Optimal: Studi Perbandingan Saham Syariah dan Saham Konvensional
}

\author{
Sri Astuti Heryanti \\ UIN Syarif Hidayatuulah Jakarta \\ sriastuti.achi29@gmail.com
}

\begin{abstract}
The aim of this study was to obtain empirical evidence about the difference between the level of risk when investing stocks in the Islamic and conventional by using Value at Risk ( $V a R)$. The object of research including consistent stock in the Jakarta Islamic Index and LQ45. The analytical method used in this research is quantitative analysis consisting of the establishment of the optimal portfolio by Markowitz method, calculation of $V a R$ and testing the differences with Independent sample t-test. This study indicated that the value every stock can be reduced by diversifying through the establishment of an optimal portfolio. Based on the calculation Independent sample t-test, it is known that there is no difference between VaR of Islamic stocks and conventional stocks.
\end{abstract}

Keywords: Value At Risk, Optimal Portfolio, Islamic Stock, Conventional Stock

\begin{abstract}
Abstrak
Tujuan penelitian ini ialah untuk mendapatkan bukti empiris perbedaan tingkat risiko antara saham syariah dan saham konvensional dengan menggunakan value at risk (VaR). Objek pada penelitian ini adalah saham-saham yang terdapat di Jakarta Islamic Index dan LQ 45. Metode analisis yang dipergunakan dalam penelitian ini analisis kuantatif dengan penggunaan metode Markowitz untuk mencari portfolio optimal, serta perhitungan VaR dan pengujian perbedaan dengan uji t bebas. Hasil penelitian mengindikasikan bahwa setiap nilai saham dapat dikurangi dengan melakukan difersifikasi melalui portfolio optimal. Berdasarkan hasil uji t bebas menunjukkan bahwa tidak terdapat perbedaan nilai VaR antara saham syariah dan saham konvensional.
\end{abstract}

Kata Kunci: Value At Risk, Portfolio Optimal, Saham Syariah, Saham Konvensional 


\section{A. PENDAHULUAN}

Perkembangan pasar bebas menjadikan kegiatan investasi banyak diminati masyarakat di Indonesia. Minat masyarakat yang tinggi tersebut membuat mereka juga menginginkan melakukan investasi di pasar modal yang berbasis syariah. Sutedi (20II) menjelaskan perbedaan mendasar pada pasar modal syariah dengan pasar modal konvensional adalah seluruh saham yang tercatat di bursa dengan mengabaikan aspek halal dan haram. Hal yang terpenting pada indeks konvensional ialah saham emiten yang terdaftar (listing) sudah sesuai aturan (legal) akibatnya bukanlah suatu persoalan jika ada emiten yang menjual sahamnya di bursa bergerak di sektor usaha yang bertentangan dengan Islam atau bersifat merusak kehidupan masyarakat.

Pasar modal syariah sendiri menunjukkan pertumbuhan yang cukup signifikan. Pertumbuhan pangsa pasar saham syariah dinilai lebih dominan dibandingkan dengan pangsa pasar saham konvensional. Data Otoritas Jasa Keuangan menyebutkan jika dilihat dari sisi produk, jumlah saham syariah tahun 2015 tercatat dalam Daftar Efek Syariah (DES) sebanyak 328 saham atau 61\% dari total kapitalisasi pasar saham Indonesia. Angka ini menunjukkan kenaikan sebesar 34\% dari tahun 20II yang hanya berjumlah 234 saham. Namun berdasarkan data Bursa Efek Indonesia jumlah investor saham syariah baru berjumlah 4.908 investor berdasarkan Single Investor Identification (SID), sehingga jumlah investor saham syariah baru mencapai I\% dari total investor saham yang jumlahnya mencapai 434.443 SID.Dengan demikian, lembaga pasar modal dan keuangan Indonesia diharapkan memberikan perhatian dan komitmennya dalam perkembangan pasar modal syariah sebagai alternatif investasi yang menguntungkan bagi investor muslim maupun investor pada umumnya.

Pada dasarnya setiap instrumen investasi baik konvensional maupun syariah yang memberikan tingkat pengembalian return akan memiliki risiko. Risiko didefinisikan sebagai kemungkinan penyimpangan dari hasil yang diharapkan (Mamduh, 2013). Untuk memperoleh tingkat keuntungan investasi yang maksimal dengan tingkat risiko tertentu, sebaiknya investor memilih beberapa saham yang dibentuk menjadi portofolio. Masalah yang sering terjadi adalah investor selalu dihadapkan dengan ketidaktahuan ketika harus memilih saham untuk dibentuk menjadi portofolio pilihannya. Sebenarnya Salah satu langkah yang dapat ditempuh untuk pengembangan pasar modal syariah diantaranya adalah penyebaran informasi kepada investor mengenai perbandingan investasi pada keuangan syariah dan konvensional. Perbandingan tersebut dapat dilakukan pada dua dimensi yaitu tingkat pengembalian yang diharapkan atau risiko dari pembentukan portofolio. 
Risiko dalam investasi terjadi akibat adanya perubahan dan pergerakan yang tidak pasti dan belum diketahui secara tepat.. Saat ini telah banyak dikembangkan perhitungan nilai risiko agar investor dapat mengetahui tingkat risiko lebih dini. Pengukuran nilai risiko yang banyak digunakan adalah Value at Risk (VaR). VaR adalah mengukur maksimum kerugian dari sebuah portofolio untuk rentang waktu tertentu pada tingkat keyakinan tertentu di bawah kondisi pasar yang normal. Secara sederhana $V a R$ ingin menjawab pertanyaan seberapa besar (dalam persen atau sejumlah uang) suatu organisasi, perusahaan dan individu dapat merugi selama waktu investasi dengan tingkat kepercayaan tertentu.Pengukuran risiko dengan metode $V a R$ saat ini sedang populer digunakan secara luas oleh industri keuangan di seluruh dunia (Buchdadi, 2008; Fauziah, 20I4).

Kajian mengenai VaR pernah dilakukan sebelumnya oleh Buchdadi (2008) Dalam penelitiannya didapatkan hasil yang menunjukan bahwa $V a R$ harian yang dihitung dengan menjumlahkan nilai $V a R$ harian komponen saham pembentuk portofolio lebih kecil dibandingkan $V a R$ portofolio tersebut. Hal ini dikarenakan tidak terjadi gejolak variansi besar pada akhir pengamatan.Penelitian lain mengenai $V a R$ dilakukan oleh Safitri (20II). Hasil penelitian menunjukkan bahwa nilai risiko dari masing-masing saham dapat diperkecil dengan melakukan diversifikasi saham dengan pembentukan portofolio.

Penelitian kali ini bertujuan untuk melihat perbedaan antara tingkat risiko apabila melakukan investasi di saham syariah dan konvensional dari sisi perhitungan Value at Risk ( $V a R$ ). Adapun secara spesifik rumusan masalah yang akan diteliti dan dikaji dalam penelitian dirumuskan dalam bentuk pertanyaan dan sebagai berikut: Pertama, berapa besar tingkat risiko investasi pada instrumen saham berbasis syariah dengan menggunakan metode $V a R$ ? Kedua, berapa besar tingkat risiko investasi pada instrumen saham berbasis konvensional dengan menggunakan metode $V a R$ ? Ketiga, apakah terdapat perbedaan antara $V a R$ saham syariah dengan $V a R$ saham konvensional?

\section{B. METODE}

Penelitian ini menggunakan analisis kuantitatif dari data - data harga saham Jakarta Islamic Index (JII) dan saham LQ45. Populasi dalam penelitian ini adalah saham-saham yang terdaftar di Bursa Efek Indonesia. (BEI). Sampel yang digunakan dalam penelitian ini adalah saham-saham yang terdaftar di Jakarta Islamic Index (JII) dan Indeks LQ45 antara tahun 20I3-20I5. Teknik pengambilan sampel adalah purposive sampling. Pertimbangan dalam menentukan 
sampel menggunakan kriteria sebagai berikut yaitu saham - saham yang konsisten terdaftar da lam JII dan LQ45 periode 20I3-20I5 secara berturut-turut, saham tersebut memiliki rata- rata return positif selama periode penelitian, saham-saham yang konsisten dan memiliki rata-rata return positif dalam JII tetapi tidak terdapat di dalam LQ45, dan saham-saham yang konsisten dan memiliki rata-rata return positif dalam LQ45 tetapi tidak terdapat di dalam JII.

Data yang diambil dalam penelitian ini merupakan data sekunder. Data tersebut diperoleh melalui berbagai cara, antara laininternet research dan library research.Metode analisa yang digunakan dalam penelitian ini adalah dengan menggunakan analisa kuantitatif yang merupakan analisis data dengan teknik perhitungan statistik. Metode analisis data yang digunakan dalam penelitian ini adalah sebagai berikut :

I. Pembentukan portofolio Optimal

Proses pembentukan portofolio optimal melibatkan beberapa tahapan sebagai berikut :

a. Menghitung Return Saham

Return masing - masing aset dihitung dengan menggunakan persamaan

b. Menghitung Standar Deviasi

$$
r=\frac{P_{t+1}-P_{t}}{P_{t}}
$$

Menghitung return saja tidak cukup untuk suatu investasi. Risiko dari investasi juga perlu diperhitungkan. Tingkat risiko dihitung dengan menggunakan standar deviasi dari return harian melalui persamaan :

$$
\sigma=\sqrt{\frac{\sum_{i=1}^{n}(R-\bar{R})^{2}}{n}}
$$

c. Menghitung Koefisien Korelasi dan Kovarians

Langkah berikutnya adalah menentukan koefisien korelasi, yang menyatakan hubungan antara return satu saham dengan return saham lainya. Secara manual koefisien korelasi dapat dihitung dengan persamaan:

$$
r_{A B}=\rho_{A B}=\frac{\operatorname{Cov}\left(R_{A} R_{B}\right)}{\sigma_{A} \sigma_{B}}
$$

Kemudian dilakukan perhitungan kovarian dan varian dari standar deviasi portofolio. Kovarian dapat dicari dengan rumus manual seperti berikut: 


$$
\operatorname{COV}\left(R_{A} R_{B}\right)=\sigma_{R a, R b}=\sum_{i=1}^{n} \frac{\left[R_{A i}-E\left(R_{A}\right) \cdot\left(R_{B i}-E\left(R_{B}\right)\right]\right.}{n}
$$

Sedangkan untuk menentukan varian dari standar deviasi harian dilakukan dengan menjumlahkan kovarian, sesuai dengan persamaan:

d. Menentukan Komposisi Optimum Portofolio Terpilih

$$
\sigma^{2} p=w_{1}^{2} \sigma_{1}^{2}+w_{2}^{2} \sigma_{2}^{2}+2 w_{1} w_{2} \operatorname{Cov}\left(r_{1}, r_{2}\right)
$$

Langkah selanjutnya adalah menentukan bobot masing-masing saham yang akan dimasukkan ke dalam portofolio. Untuk menentukan jenis bobot saham tersebut digunakan bantuan solver di software Ms. Excel, sehingga akan didapat kombinasi aset yang memberikan perbandingan imbal hasil risiko terbaik.

2. Pengukuran $\mathrm{VaR}$

Nilai $\mathrm{VaR}$ portofolio dihitung dengan rumus :

$$
V a R=\alpha \sigma_{p} W \sqrt{t}
$$

Nilai $\mathrm{VaR}$ yang dihitung adalah nilai $\mathrm{VaR}$ harian yang menunjukkan besarnya kerugian yang dihadapi investor

3. Uji Beda

Dalam penelitian ini uji beda yang dilakukan adalah uji t dua sampel bebas (independent sample t test). Uji ini akan membandingkan rata-rata dari dua grup yang tidak berhubungan satu dengan yang lainya. Analisis mengenai uji dapat dilakukan berdasarkan dua cara :

a. Berdasarkan perbandingan $t$ hitung dan $t$ tabel

I) Jika nilai thitung $<$ nilai $t$ tabel maka $\mathrm{H}_{0}$ diterima

2) Jika nilai thitung $>$ nilai t tabel maka $\mathrm{H}_{0}$ ditolak

b. Berdasarkan nilai probabilitas

I) Jika probabilitas $>$ sig 0,05 maka Ho diterima

2) Jika Probabilitas < sig 0,05 maka Ho ditolak

\section{HASIL DAN PEMBAHASAN}

Portofolio dapat dibentuk dari dua aktiva namun di pasar modal tidak hanya terdiri dari dua aktiva tetapi banyak aktiva. Banyak aktiva memunculkan banyak sekali kemungkinan portofolio yang dapat dibentuk dari kombinasi aktiva berisiko yang terdapat di pasar. Kombinasi ini dapat mencapai jumlah yang tidak terbatas. Jika terdapat kemungkinan portofolio yang tidak terbatas, maka akan timbul pertanyaan portofolio mana yang akan dipilih oleh investor. Jika investor adalah rasional, maka mereka akan memilih portofolio yang optimal (Jogiyanto, 2007) 
Secara umum, portofolio optimal adalah portofolio dengan kinerja yang terbaik. Terdapat banyak konsep untuk mengukur kinerja portofolio ini. Salah satu konsep pengukuran kinerja portofolio yang banyak digunakan adalah hasil kombinasi return portofolio dibagi dengan risiko portofolionya. Oleh karena itu, secara khusus, portofolio optimal adalah portofolio yang memberikan hasil kombinasi return tertinggi dengan risiko yang terendah.

Saham yang akan dipakai dalam penelitian ini adalah saham yang masuk dalam kategori saham JII selama periode penelitian yaitu dari Januari 20I3Desember 2015. Saham-saham tersebut juga harus memiliki rata -rata return harian positif dan akhirnya didapat lima saham untuk membentuk suatu portofolio optimal. Tabel I adalah daftar saham yang menjadi saham terpilih:

\section{Tabel I}

Daftar Saham JII Untuk Portofolio Optimal

\begin{tabular}{cll}
\hline No & \multicolumn{1}{c}{ Saham } \\
\hline I & AKRA & PT AKR Corporindo Tbk \\
2 & BSDE & PT Bumi Serpong Damai Tbk \\
3 & ICBP & PT Indofood CBP Sukses Makmur \\
& & Tbk \\
4 & KLBF & PT Kalbe Farma Tbk \\
5 & UNVR & PT Unilever Tbk \\
\hline
\end{tabular}

Sumber : Data Diolah

Sedangkan saham konvensional yang akan dipakai dalam penelitian ini adalah saham yang masuk dalam kategori saham LQ45 selama periode penelitian yaitu dari Januari 2013- Desember 2015. Saham-saham tersebut memiliki rata -rata return harian positif dan tidak merupakan saham yang termasuk kategori JII, akhirnya didapat enam saham untuk membentuk suatu portofolio optimal. Tabel 2 adalah daftar saham konvensional yang menjadi saham terpilih.

\section{Tabel 2}

\section{Daftar Saham LQ45 Untuk Portofolio Optimal}

\begin{tabular}{cll}
\hline No & & \multicolumn{1}{c}{ Saham } \\
\hline I & BBCA & PT Bank Central Asia Tbk \\
2 & BBNI & PT Bank Negara Indonesia Tbk \\
3 & BBRI & PT Bank Rakyat Indonesia Tbk \\
4 & BMRI & PT Bank Mandiri \\
5 & GGRM & PT Gudang Garam Tbk \\
6 & JSMR & PT Jasa Marga Tbk \\
\hline
\end{tabular}


Solver add-ins membantu menentukan komposisi portofolio yang optimal. Portofolio optimal yang dipilih adalah portofolio dengan risiko terkecil, dengan berdasarkan kepada nilai varian minimal (minimum variance portofolio). Dengan bantuan solver maka didapatkan komposisi saham sebagaimana pada Tabel 3.

\section{Tabel 3}

Komposisi Saham Portofolio Optimal JII

\begin{tabular}{lrrrrr}
\hline Saham & \multicolumn{1}{c}{ AKRA } & BSDE & \multicolumn{1}{c}{ ICBP } & \multicolumn{1}{c}{ KLBF } & UNVR \\
\hline Mean & $0.05 \%$ & $0.03 \%$ & $0.05 \%$ & $0.01 \%$ & $0.05 \%$ \\
$\boldsymbol{\sigma}$ & $2.37 \%$ & $2.64 \%$ & $2.01 \%$ & $2.09 \%$ & $2.06 \%$ \\
Proporsi & $22.44 \%$ & $4.25 \%$ & $28.95 \%$ & $16.94 \%$ & $27.42 \%$ \\
\hline
\end{tabular}

Sumber : Data diolah

Setelah dilakukan perhitungan maka diperoleh portofolio optimal JII dengan proporsi saham AKRA sebesar 22,44\%, BSDE sebesar 4,25\%, ICBP sebesar $28,95 \%$, KLBF sebesar I6,94\% dan UNVR sebesar 27,42\%. Saham ICBP merupakan saham dengan proporsi dana terbesar dalam portofolio, hal ini dikarenakan nilai standar deviasi saham ICBP merupakan nilai yang terkecil. Portofolio optimal tersebut terbentuk berdasarkan risiko terkecil dengan nilai minimum variance portofolio sebesar $1.49 \%$. Portofolio ini memiliki rata-rata return $0.04 \%$ dengan standar deviasi $\mathrm{I} .49 \%$.

\section{Tabel 4}

Komposisi Saham Portofolio Optimal LQ45

\begin{tabular}{lrrrrr}
\hline Saham & \multicolumn{1}{c}{ BBCA } & BBNI & \multicolumn{1}{c}{ BMRI } & GGRM & JSMR \\
\hline Mean & $0.03 \%$ & $0.01 \%$ & $0.01 \%$ & $0.02 \%$ & $0.03 \%$ \\
$\boldsymbol{\sigma}$ & $1.69 \%$ & $2.16 \%$ & $1.75 \%$ & $2.33 \%$ & $1.88 \%$ \\
Proporsi & $26.53 \%$ & $2.52 \%$ & $30.47 \%$ & $15.60 \%$ & $24.88 \%$ \\
\hline \multicolumn{4}{l}{ Sumber : Data diolah }
\end{tabular}

Komposisi portofolio optimal LQ45 berdasarkan tabel 4 terdiri dari saham BBCA dengan proporsi dana 26,53\%, BBNI dengan proporsi dana sebesar 2,52\%, BMRI dengan proporsi dana 30,47\%, GGRM dengan proporsi dana sebesar I5.60\%, dan JSMR dengan proporsi dana $24.88 \%$. Saham yang masuk menjadi portofolio optimal hanya lima karena saham BBRI nilai proporsi dananya hanya $0,00 \%$. Portofolio optimal terbentuk berdasarkan nilai minimum variance portofolio sebesar $1.64 \%$ dan portofolio ini memiliki nilai rata-rata return $0.02 \%$ dengan standar deviasi I.64\%.

Berdasarkan Tabel 5 dapat disimpulkan bahwa dengan tingkat kepercayaan 95\% maka potensi risiko yang terdapat pada saham AKRA adalah 4,I2\%. Potensi 
Perhitungan Value at Risk Pada Portfolio Optimal:

Studi Perbandingan Saham Syariah dan Saham Konvensional

(Sri Astuti Heryanti)

risiko yang terjadi pada saham BSDE adalah 3,4I\%. Pada saham ICBP terdapat potensi risiko sebesar 3.I8\%. KLBF memiliki potensi risiko sebesar 3,4I\% dan UNVR memilki potensi risiko sebesar 3,0I\%. Portofolio optimal JII memiliki potensi risiko sebesar $2.50 \%$.

\section{Tabel 5}

\begin{tabular}{clc}
\multicolumn{3}{c}{ Hasil Perhitungan VaR Saham JII } \\
\hline No & Saham & VaR \\
\hline I & AKRA & $4.12 \%$ \\
2 & BSDE & $3.41 \%$ \\
3 & ICBP & $3.18 \%$ \\
4 & KLBF & $3.41 \%$ \\
5 & UNVR & $3.01 \%$ \\
6 & PORTOFOLIO & $2.50 \%$ \\
\hline
\end{tabular}

Sumber: Data diolah

Sementara itu,Tabel 6 menunjukkan bahwa saham BBCA memiliki potensi risiko sebesar 3.87\%. Pada saham BBNI terdapat potensi risiko sebesar 3,42\%. Potensi risiko yang ada pada saham BMRI adalah sebesar 2.87\%. GGRM memiliki potensi risiko sebesar 4,45\%, JSMR memilki potensi risiko sebesar 3,16\% dan Portofolio memiliki potensi risiko sebesar 2,74\% .

Tabel 6

\begin{tabular}{|c|c|c|}
\hline \multicolumn{3}{|c|}{ Hasil Perhitungan VaR Saham LQ45 } \\
\hline No & Saham & $\mathrm{VaR}$ \\
\hline $\mathrm{I}$ & BBCA & $3.87 \%$ \\
\hline 2 & BBNI & $3.42 \%$ \\
\hline 3 & BMRI & $2.87 \%$ \\
\hline 4 & GGRM & $4.45 \%$ \\
\hline 5 & JSMR & $3.16 \%$ \\
\hline 6 & PORTOFOLIO & $2.74 \%$ \\
\hline
\end{tabular}

Sumber : Data diolah

Dalam penelitian ini uji beda yang dilakukan adalah uji t dua sampel bebas (independent sample $t$ test). Berdasarkan hasil perhitungan $t$ test diketahui bahwa nilai t hitung sebesar -0.0425 lebih kecil dari nilai t tabel sebesar 2,633, nilai probablitas (sig. 2 tailed) yaitu 0,680 lebih besar dari nilai probabilitas $95 \%$ yaitu 0,05 . Dengan demikian dapat disimpulkan bahwa Ho diterima yaitu tidak terdapat perbedaan antara $\mathrm{VaR}$ saham JII dan VaR saham LQ45. Hasil ini menunjukan bahwa tidak ada perbedaan dalam hal perhitungan risiko baik saham syariah dan konvensional. Hal ini dikarenakan secara umum perbedaan saham syariah dan 
saham konvensional hanya terdapat pada dasar hukum operasional emiten dan cara bertransaksi.

Hal serupa ditemukan pula oleh Maskur (2009), Esha, dkk (20I4) dan Rosyida dan Mawardi (2015) menemukan bahwa tidak terdapat perbedaan ratarata kinerja reksa dana saham syariah dengan saham konvensional. Bahkan, kinerja reksa dana saham syariah lebih baik jika dibandingkan dengan kinerja reksa dana saham konvensional (Esha, dkk, 20I4). Namun, Syafrida, dkk (20I4) menemukan bahwa tidak terdapat perbedaan kinerja antara saham syariah dan saham konvensional. Tanjung (20I4) menemukan bahwa tingkat pengembalian pada Jakarta Islamic Index volatilitasnya terlalu tinggi dibandingkan dengan yang diprediksi. Hal ini dapat mengakibatkan tingginya keuntungan atau bahkan kerugian dalam satu hari.

\section{Tabel 7}

\section{Hasil Uji Beda}

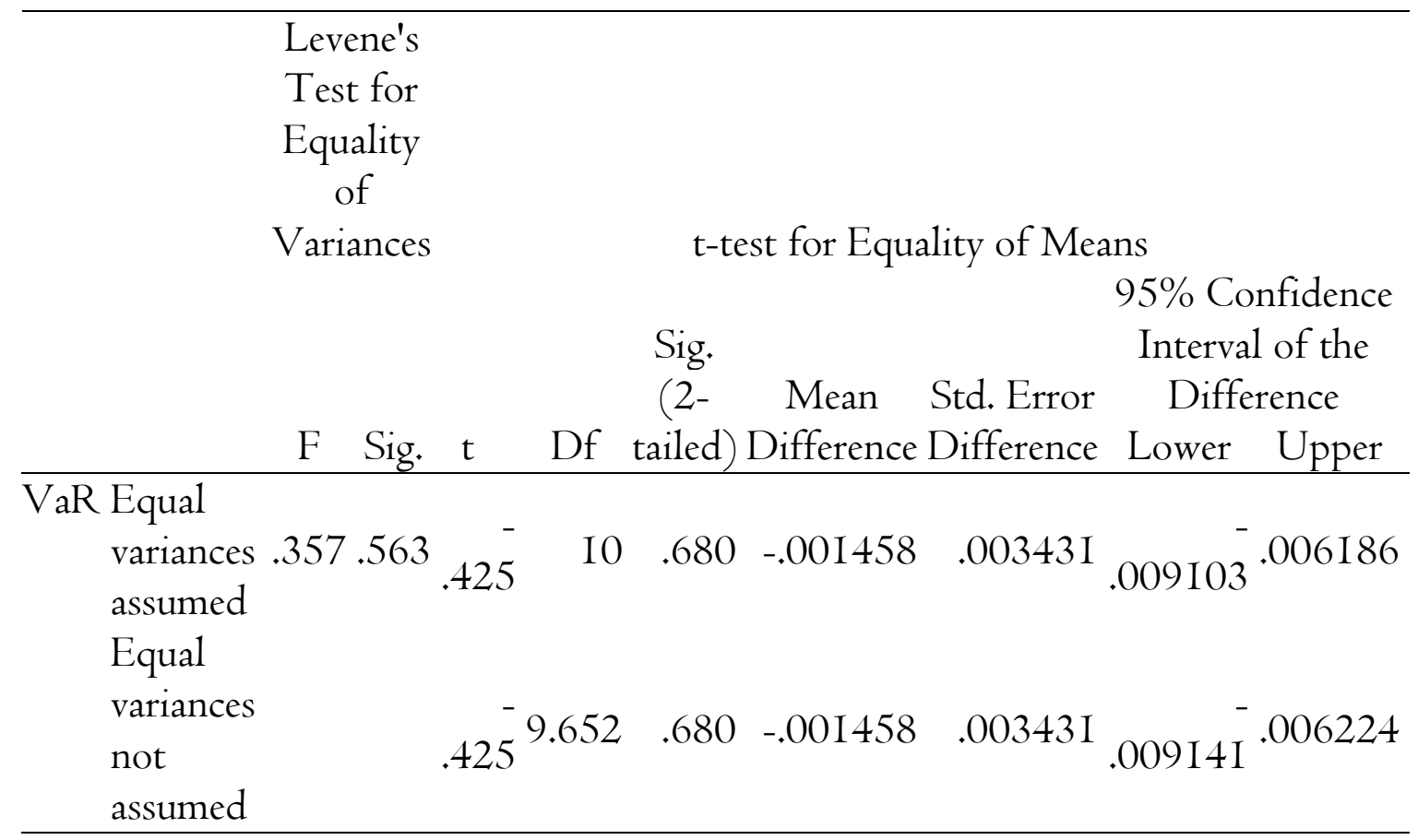

Sumber: Hasil output SPSS

\section{SIMPULAN}

Berdasarkan hasil analisis data dapat diketahui bahwa portofolio optimal saham syariah dan konvensional sama -sama terdiri dari 5 saham. Saham - saham syariah maupun konvensional yang telah dilakukan optimalisasi memiliki nilai potensi risiko yang lebih kecil dibandingkan potensi risiko masing-masing saham pada perhitungan VaR. Pada dasarnya antara potensi risiko portofolio optimal 
saham syariah dan portofolio optimal saham konvensional adalah sama. Ini terbukti dari hasil perhitungan uji beda yang menunjukkan bahwa t hitung sebesar -0.0425 lebih kecil dari nilai t tabel sebesar 2,633, nilai probablitas (sig. 2 tailed) yaitu 0,680 lebih besar dari nilai probabilitas $95 \%$ yaitu 0,05 sehingga diketahui bahwa tidak ada perbedaan dalam hal perhitungan risiko baik saham syariah dan konvensional.

Namun secara perhitungan matematis dari segi risiko, portofolio saham syariah memilki nilai potensi risiko yang lebih kecil yaitu 2,50\% jika dibandingkan dengan portofolio optimal saham konvensional yang memiliki potensi risiko sebesar 2,74\%. Dengan demikian diharapkan para investor tertarik dengan saham syariah karena memiliki potensi risiko yang lebih kecil dan investor juga tidak perlu khawatir dengan potensi risiko yang akan diterima, karena berdasarkan hasil perhitungan tersebut risiko masih tergolong rendah dan masih dapat ditoleransi bagi investor yang takut akan risiko (risk averse).

\section{PUSTAKA ACUAN}

Buchdadi, A.D.(2008). Perhitungan Value at Risk Portofolio Optimum Saham Perusahaan Berbasis Syariah dengan Pendekatan EMWA. Jurnal Akuntansi dan Keuangan Indonesia. Vol. 5 (2): I82-20I.

Esha, M.R., Heykal, M. dan Indrawati, T. (20I4). Analisis Perbandingan Reksa Dana Saham Syariah dengan Reksa Dana Saham Konvensional Periode 200920I2. Binus Business Review. Vol. 5 (I): 230-240.

Fauziah, M. (20I4). Analisis Risiko Pada Portfolio Saham Syariah Menggunakan Value at Risk (VaR) dengan Pendekatan Generalized Pareto Distibution (GPD). Jurnal Konvergensi. Vol. 4 (2): 85-106.

Jogiyanto. (2007). Teori Portofolio dan Analisis Investasi. Yogyakarta: BPFE Yogyakarta

Mamduh, H. (2013). Manajemen Keuangan. Yogyakarta : BPFE-Yogyakarta.

Maskur, A. (2009). Volatilitas Harga Saham Antara Saham Konvensional dan Saham Syariah. Dinamika Keuangan dan Perbankan. Vol. I (2): 82-94.

Muthoharoh dan Sutapa. (20I4). Perbandingan Saham Berbasis Syariah dengan Saham Konvensional sebagai Analisa Kelayakan Investasi Bagi Investor Muslim. Jurnal Akuntansi Indonesia. Vol. 3 (2): IOI-I I2.

Rosyida, A.G., dan Mawardi, I. (20I5). Perbandingan Tingkat Pengembalian (Return), Risiko, dan Koefisien Variasi Pada Saham Syariah dan Saham Non Syariah di Bursa Efek Indonesia Periode 20II-20I3. JESTT. Vol. 2 (4): 288-304.

Sutedi, A. (20I I). Pasar Modal Syariah. Jakarta : Sinar Grafika

Syafrida, I., Aminah, I., dan Waluyo, B. (20I4). Perbandingan Kinerja Instrumen Investasi Berbasis Syariah dengan Konvensional di Pasar Modal Indonesia. AlIqtishad: Jurnal Ilmu Ekonomi Syariah (Journal of Islamic Economics). Vol. $6(2): 195-206$.

Tanjung, H. (20I4). Volatility of Jakarta Islamic Index. Al-Iqtishad: Jurnal Ilmu Ekonomi Syariah (Journal of Islamic Economics). Vol. 6 (2): 207-222. 